\title{
O Documento de Aparecida e sua proposta para toda a Igreja
}

\author{
The Aparecida Document and its proposal \\ for the whole Church
}

D. Joel Portella Amado

\section{Resumo}

Dentro das celebrações do décimo aniversário da Conferência de Aparecida, o presente artigo reflete sobre a especificidade daquela conferência e de seu documento conclusivo. Ratifica a perspectiva universal de um evento que foi geoculturalmente localizado e indica a mudança de época como o eixo condutor da reflexão e da proposta de Aparecida. Esta realidade leva à proposta de se recomeçar a partir de Jesus Cristo, numa Igreja que se configura como comunidade de comunidades, a serviço da vida. Reflete ainda sobre alguns processos vivenciados pelo mundo, em especial pelo continente latinoamericano na última década, trata do modo como a Igreja no Brasil acolheu o Documento de Aparecida, indicando, ao final, preocupações e prospectivas.

Palavras-chave: Conferência de Aparecida. Documento de Aparecida. Retrospectiva. Prospectiva.

\begin{abstract}
Within the celebrations of the tenth anniversary of the Conference of Aparecida, this article reflects on the specificity of that conference and its conclusive document. It ratifies the universal perspective of an event that was geoculturally located and indicates the change of era as the guiding axis of the reflection and the proposal of Aparecida. This reality leads to the proposal to start once more from Jesus Christ, in a Church that is configured
\end{abstract}


as a community of communities, at the service of life. The article also reflects on some of the processes experienced by the world, especially in the Latin American continent in the last decade and about the way the Church in Brazil welcomed the Aparecida Document, indicating, in the end, concerns and prospects.

Keywords: Conference of Aparecida. Document of Aparecida. Retrospective. Prospective.

\section{Introdução}

O título de proposta para toda a Igreja pode ocasionar algum tipo de estranhamento, pois as Conferências Continentais latino-americanas, como o próprio nome indica, são geoculturalmente localizadas. Não se destinam à universalidade da Igreja. Na sua gênese, está o encontro da consciência evangelizadora com os desafios de um determinado lugar, num determinado tempo. No entanto, na busca pela identidade de Aparecida, é possível afirmar que as conclusões daquela Conferência trazem em si uma peculiar característica de universalidade. Esta universalidade decorre de dois motivos.

Em primeiro lugar, decorre da relação entre o então presidente da comissão de redação do Documento e o atual Papa. Como sabemos, tratase da mesma pessoa, arcebispo de Buenos Aires durante a Conferência e, seis anos mais tarde, o Papa Francisco. De fato, o atual pontífice tem no Documento de Aparecida uma referência para o modo como compreende a ação evangelizadora. Por diversas vezes, tem mencionado o Documento de Aparecida como inspiração para o que se pode e deve fazer em termos de evangelização. Por exemplo, a assim chamada carta magna de seu pontificado, ou seja, a Exortação Apostólica Evangelii Gaudium, encontra-se em direta conexão com as conclusões de Aparecida. Temos uma dezena de citações diretas de Aparecida, uma vez no corpo do texto da Exortação, quando trata da piedade popular $\left(n^{0} 124\right)$ e as restantes em notas de rodapé. ${ }^{1}$ Por certo, não se trata de estabelecer uma correlação de forças entre as diversas fontes usadas pelo Papa Francisco ao escrever a Evangelii Gaudium, mas, a partir dessa

\footnotetext{
${ }^{1}$ PAPA FRANCISCO. Evangelli Gaudium. A alegria do Evangelho sobre o anúncio do Evangelho no mundo atual. São Paulo: Paulus/Loyola, 2013, notas 4, 13, 17, 21, 63, 98, 103, 106 e 147.
} 
indicação quantitativa, de acenar para a influência transversal de Aparecida na Evangelii Gaudium, no pontificado do Papa Francisco e consequentemente em toda a Igreja.

O segundo motivo dessa universalização de Aparecida encontra-se no que podemos chamar de seu DNA, ou seja, em seu eixo central, percebido pelos participantes da Conferência, destacado pelo Papa Francisco e que podemos chamar de universalização. Sabemos que documentos como este passam por um processo que pode ser visto em três partes: a preparação, a construção e a apropriação. Em cada uma dessas etapas, uma pergunta sempre se mantém, ainda mais no caso das nossas Conferências Continentais: a ligação entre o desafio evangelizador e o contexto que se apresenta diante de nós. Na etapa da preparação, havia o desafio de se recolher as Conferências anteriores e suas conclusões, buscando uma linha de continuidade com o que se pode chamar de identidade da Igreja latino-americana. ${ }^{2}$ Como sabemos, é possível estabelecer conexões e desconexões entre Puebla e Santo Domingo e um dos desafios da etapa de construção consistia em discernir qual o caminho a ser seguido, uma vez que a desconexão soava mais forte. A solução foi encontrada. Porém, na etapa da apropriação, ela não foi percebida de imediato. Foi necessário um tempo de ruminação para que se pudesse ultrapassar o olhar pontual, isto é, o que busca este ou aquele tema dentro do texto, para um olhar mais abrangente ou mesmo transversal. Por isso, é muito importante considerar a etapa de apropriação do Documento por pessoas e comunidades.

\section{O acolhimento de Aparecida}

O fato é que o Documento ${ }^{3}$ foi bem acolhido. O modo como a Conferência foi realizada, com especial destaque para o local, o tempo desde a anterior (15 anos) e as diferenças entre Puebla e Santo Domingo ajudaram a incrementar a curiosidade sobre Aparecida. Foram muitos os encontros, os cursos e outros eventos para refletir sobre o Documento de Aparecida. Foi necessário um tempo para que se pudesse ultrapassar as expectativas imediatas em relação

\footnotetext{
${ }^{2}$ Sobre o histórico desta identidade ver, por exemplo: BENI DOS SANTOS, B. "A identidade da Igreja latino-americana de Medellín a Santo Domingo". Revista de Cultura Teológica 2 (1993), pp. 7-17.

${ }^{3}$ CELAM. Documento de Aparecida. Texto conclusivo da V Conferência Geral do Episcopado Latino Americano e do Caribe. Brasília-DF/Rio de Janeiro: Edições CNBB/Paulus/Paulinas, 2007. Doravante citado pela sigla DAp.
} 
ao Documento e perceber que estávamos diante de uma novidade, uma compreensão que ultrapassava a leitura em chave de embate entre Puebla e Santo Domingo, esperando que Aparecida resolvesse a questão, como que desempatando uma final de campeonato desportivo.

Aparecida resolveu o impasse entre continuidade e descontinuidade Puebla-Santo Domingo. E ela o fez dando um salto qualitativo na compreensão da realidade e da ação evangelizadora e é exatamente este salto, esta novidade, que 1) fornece identidade muito específica ao Documento e 2) permite que o mesmo, apesar de ser um Documento surgido para enfrentar uma realidade local, se abra à universalidade da Igreja.

\section{O método ver-julgar-agir}

O ponto de partida da novidade de Aparecida encontra-se no método de captação da realidade. Puebla, conforme a consciência teológica e pastoral daquele momento, seguiu o método ver, julgar e agir. Críticas subsequentes consideraram que o uso deste método poderia condicionar a captação da Revelação, subjugando-a à base a partir da qual se estivesse captando a realidade. Com isso, se temia que a primazia do anúncio do dado revelado saísse maculada pela prévia análise da realidade. Dentre outras coisas, foi este o motivo que levou Santo Domingo a escolher um outro método para pensar a evangelização na América Latina. Naquela Conferência, que celebrava os 500 anos de presença do Evangelho nas terras da América (1992), optou-se por partir da afirmação do dado revelado e tirar, então, as devidas consequências.

Não desejando julgar o passado com os olhos do presente, convém, entretanto, aprender com a história. Este aspecto é importante, porque nossas Conferências Continentais se caracterizam exatamente pela articulação entre o dado da realidade e o dado da Revelação. Não se trata de um ou de outro, mas de discernir como se dá o encontro entre um e outro em determinado momento da história do Continente. Seja colocando o peso no dado da realidade, seja o colocando no dado da Revelação, o dualismo permanece, desaparecendo, portanto, a indispensável articulação entre ambos para que a ação evangelizadora aconteça.

A lógica das Conferências continentais segue um caminho usual para se pensar qualquer ação evangelizadora: olhamos a realidade que nos desafia, buscamos os instrumentos com os quais vamos enfrentar os desafios e tomamos decisões. As Conferências Continentais não são encontros para tratar de todos 
os assuntos relativos à fé. Não se destinam a escrever tratados de teologia. Não intentam produzir sumas teológicas nem enfrentar todos os desafios que a realidade, cada dia mais complexa, nos apresenta. As Conferências latinoamericanas e caribenhas se caracterizam pelo desejo de discernir o caminho evangelizador e isso se faz através do encontro entre a realidade e o dado revelado. ${ }^{4}$

Aparecida teve, portanto, o mérito de não apenas retornar ao método verjulgar-agir, mas de mostrar que todo ver é sempre um ver situado. Mostrou que a realidade, em razão de sua complexidade, pode ser captada sob prismas diversos. Por isso, Aparecida não apenas fez a escolha pelo método verjulgar-agir, como também explicitou o lugar a partir do qual estava captando a realidade, ou seja, o lugar do(a) discípulo(a) de Jesus Cristo. A realidade é a mesma, com sua complexidade. Muitos olham para ela buscando discernir os caminhos de interação. A Conferência de Aparecida também fez isso, identificando, com o que podemos considerar honestidade metodológica, de onde estaria contemplando a realidade. Assim, o Documento ganhou sua primeira parte, com dois capítulos; o primeiro, em seu conjunto, com somente 12 números marginais (DAp 20-32) dedica-se, ao mesmo tempo, a começar a descrever a realidade, indicando que o olhar é o de discípulos missionários. Por sua vez, a leitura da realidade torna-se o terceiro capítulo, com um esforço grande de compreender a complexidade em seus vários aspectos: sociocultural, econômico, sociopolítico, ecológico e cultural.

Em tudo isso, não se pode passar muito rapidamente pelo número 19 de Aparecida. Nesta espécie de introdução à primeira parte do Documento, os participantes da Conferência explicitam que fizeram clara opção pelo método, por sua validade e o prisma a partir do qual assumiram essa decisão. Interessante observar que este processo de discernimento do método a ser seguido antecedeu à própria Conferência, já aparecendo na preparação, conforme oficialmente transcrito para o Documento na nota 18 ao mesmo, referente à síntese das contribuições recebidas para a Conferência, síntese organizada pelo CELAM. Eis alguns trechos mais relevantes do número 19 de Aparecida:

"Em continuidade com as Conferências Gerais anteriores do Episcopado Latino-americano, este documento faz uso do método "ver, julgar e

\footnotetext{
${ }^{4}$ Cf. STANOVINIC, A. "El método ver-juzgar-agir en Aparecida”. In: CELAM (Org.). Testigos
} de Aparecida. Vol. II. Bogotá: CELAM, 2008, pp. 103-135. 
agir". Este método implica em contemplar a Deus com os olhos da fé ... Muitas vozes, vindas de todo o Continente ofereceram contribuições e sugestões nesse sentido, afirmando que este método tem colaborado para que vivamos mais intensamente nossa vocação e missão na Igreja: tem enriquecido nosso trabalho teológico e pastoral e, em geral, tem-nos motivado a assumir nossas responsabilidades diante das situações concretas de nosso continente. Este método nos permite articular, de modo sistemático, a perspectiva cristã de ver a realidade; a assunção de critérios que provêm da fé e da razão para seu discernimento e valorização, com sentido crítico; e, em consequência, a projeção do agir como discípulos missionários de Jesus Cristo".

\section{O que o discípulo viu}

Numa realidade tão complexa, aspectos é que não escasseiam. De fato, quando olhamos os temas abordados ao longo dos dez capítulos do Documento, percebemos o desejo que os participantes da Conferência tiveram de poder dar uma palavra de fé para uma realidade em crescente grau de complexidade. É por isso que, de algum modo, Aparecida aborda inúmeros temas. Basta ver o índice analítico ou temático, presente na maioria das edições. A questão, porém, consiste não em buscar este ou aquele tema em separado, mas em, acima de tudo, identificar qual seja a linha transversal a todo o documento, qual seja, portanto, o DNA de Aparecida. Seria uma continuidade com Medellín e Puebla ou, se lidas essas Conferências em chave de oposição, com Santo Domingo?

Aparecida não se ateve a olhar o passado e se preocupar apenas em resgatar esse ou aquele tema, quer com o enfoque de Puebla (1979, 28 anos antes) quer com o enfoque de Santo Domingo (1992, 15 antes). Aparecida mostrou a existência de um dado novo na realidade, dado que precisava urgentemente ser assumido pela consciência eclesial. Esse dado aparece exatamente na leitura da realidade, sem a qual talvez não tivesse sido captado. Daí a importância de se ter a realidade como ponto de partida nesse tipo de encontro e reflexão pastoral. É por isso que o capítulo segundo torna-se indispensável, como chave de leitura, para quem deseja compreender Aparecida. Em consequência, os demais temas, sejam quais forem, só podem ser compreendidos se vistos a partir deste prisma transversal. Caso contrário, soluções anacrônicas podem ser indicadas para questões que se manifestam de outro modo e, mais ainda, as concepções de Igreja e de ação evangelizadora podem não considerar aspectos 
muito importantes assumidos pela Conferência de Aparecida, registrados no Documento dela surgido e ampliados para a totalidade da Igreja através do pontificado do Papa Francisco.

\section{O fio condutor de Aparecida}

Sobre essa linha transversal, muito já se falou. Pouco meses depois da Conferência, em uma Semana Teológica levada a efeito pelo Departamento de Teologia da PUC-Rio, os olhares sobre Aparecida eram de ratificação. Perguntava-se se Aparecida ratificaria esta ou aquela opção, este ou aquele jeito de ser igreja, esta ou aquela perspectiva de ação evangelizadora. Aparecida, no entanto, abriu horizontes muito mais amplos do que somente resgatar ou rejeitar. Aparecida mostrou que a desafiadora realidade carregava consigo elementos novos, não considerados pelas Conferências anteriores porque, na época das mesmas, tais elementos não tinham ainda adquirido a força de que se revestiram no final do século XX e no início do século XXI. Não sendo fatores de surgimento abrupto, eis que gerados lentamente no século passado, estes fatores, porém, se tornaram agudos exatamente no período da história do continente sobre o qual Aparecida deteve o seu olhar.

Para compreender que fatores são esses, fatores que constituem o DNA de Aparecida, podemos recorrer a alguns dos números do Documento. Tratase do conjunto de parágrafos entre os números 33 e 40. Neles, a meu ver, se apresenta a perspectiva de Aparecida para a compreensão da realidade. Seu título é exatamente "a realidade que nos desafia como discípulos e missionários". Nestes parágrafos, Aparecida fala de mudanças. Usa o termo quatro vezes em oito parágrafos. Afirma que "os povos da América Latina e do Caribe vivem hoje uma realidade marcada por grandes mudanças que afetam profundamente suas vidas". É com esta frase que se inicia o número 33 e o capítulo segundo. Afirma ainda que tais mudanças são diferentes do "ocorrido em outras épocas" (DAp 34), que possuem um alcance global, ainda que de forma diferente nos povos e nas culturas (idem), com consequências para todos os âmbitos da vida humana, inclusive o religioso (DAp 35). Conclui afirmando que, em face dessas mudanças, a realidade se torna cada vez mais "sem brilho e complexa" (DAp 36), ou seja, confusa para os que nela vivem, com um grau de incerteza bastante significativo, trazendo em si uma consequente e inseparável "crise de sentido", não dos sentidos parciais, cotidianos, mas do sentido global da existência (DAp 37). Aparecida assume para a Igreja, 
pelo menos para a Igreja do Continente latino-americano e caribenho, o que exaustivamente se tem denominado como mudança de época. Esta expressão é claramente descrita no número 44.

A questão é que Aparecida não para aí em seu discernimento da realidade. Nos números 37 e 38, acrescenta um segundo fator que não pode ser desprezado. Trata-se da relação que a realidade tem com a dimensão religiosa ou, se quisermos ampliar o leque de compreensão, com a vivência da fé. Aparecida recorda que, para os latino-americanos e caribenhos, a fé se constituiu num fator, se assim podemos dizer, de resistência aos inúmeros desafios (DAp 37). A novidade é que "essa preciosa tradição começa a se diluir" (DAp 38), a ponto e não ser mais capaz de "transmitir os valores culturais de uma geração a outra com a mesma fluidez que no passado" (DAp 39).

Interessante observar que Aparecida não se refere à transmissão da fé, mas sim à tradição cultural própria do continente, na qual se insere a fé. Para Aparecida, tivemos uma história de forte conexão entre a fé cristã e as culturas dos povos latino-americanos e caribenhos (DAp 37), de tal modo que falar da transmissão de uma implica necessariamente falar da transmissão da outra. Ao dizer que isso já não acontece, pelo menos com a mesma fluidez de antes, Aparecida assume oficialmente o fato de não sermos mais uma cultura ou culturas cristãs. O processo de quebra da identidade entre ser latino-americano e ser cristão se rompe no sentido de que os mecanismos de inserção na cultura já não só não inserem nas dinâmicas da fé, ou seja, já não possibilitam a transmissão da fé, como também rumam em outra direção, a saber, a de uma cultura marcada, no dizer de Aparecida, pela "informação de último minuto, a distração, o entretenimento, as imagens dos vencedores que souberam usar a seu favor as ferramentas tecnológicas e as expectativas de prestígio e estima social" (DAp 39). Com isso, Aparecida afirma que, após vários séculos de identificação entre o cultural e o religioso cristão no continente (DAp 37) , ingressamos num novo período histórico-cultural em que o cristianismo já não possui a força aglutinadora do sentido existencial, perdendo fôlego diante de um processo, de acordo com a compreensão de Aparecida, altamente individualizante (DAp 44 e 47). Aparecida, com isso,

\footnotetext{
${ }^{5}$ DAp 37: "Em nossa cultura latino-americana e caribenha conhecemos o papel tão nobre e orientador que a religiosidade popular desempenha, especialmente a devoção mariana, que contribuiu para nos tornar mais conscientes de nossa comum condição de filhos de Deus e de nossa comum dignidade perante seus olhos, não obstante as diferenças sociais, étnicas ou de qualquer outro tipo".
} 
declara que a modernidade desembarcou no continente para a inumação da cristandade.

A partir do número 44, são então descritas inúmeras características do que, na compreensão dos bispos, é o fato gerador de todas as demais situações, fato igualmente condicionador das respostas a serem discernidas para a ação evangelizadora na América Latina e no Caribe. É o que, por quatro vezes, o Documento de Aparecida chama de nova cultura. ${ }^{6}$ Embora, à primeira vista, pareça um número pequeno de referências dentro do Documento, se considerarmos o quadro milenar de identificação entre a experiência cristã e a cultura ocidental, conseguimos explicitar ainda mais a percepção do que venha a ser o DNA de Aparecida.

\section{O diagnóstico se faz proposta}

Este mesmo DNA se manifesta na proposta pastoral específica de Aparecida. Sabemos que, dentro do Documento, existem inúmeras propostas ligadas a temas pontuais. Para esta reflexão, importa, como já dito antes, o olhar maior, a perspectiva mais ampla e transversal. Esta se encontra textualmente apresentada somente em três números do Documento. Contextualmente, entretanto, ela se faz presente em todo o Documento de Aparecida. Os três números são os conhecidíssimos 12, 41 e 549. Nos três, aparece explicitada a proposta de "recomeçar a partir de Jesus Cristo", com o singular detalhamento que aparece no número 549, que afirma não podermos "dar nada como pressuposto e descontado", ou seja, estamos num tempo de começar do zero. Aquilo que Paulo VI, na Evangelii Nuntiandi ${ }^{7}$ havia intuído como o maior "drama da nossa época" (EN 20), Aparecida afirma e confirma para o continente, cuja base religiosa sempre foi o patamar de resistência em face dos desafios. Aparecida nos mostra que hoje regressamos ao hall do processo evangelizador, ou seja, não estamos sequer na sala de visitas, embora possamos continuar achando que somos os donos da casa.

Quando, pois, a grande proposta se torna a apresentação da pessoa e da mensagem de Jesus Cristo, devemos considerar que ela já não é mais conhecida.

\footnotetext{
${ }^{6} \mathrm{DAp} 51,486 \mathrm{a}, 486 \mathrm{~h}$ e 513. O termo, apesar de aplicado especificamente à questão dos meios de comunicação social, pode ter sua leitura ampliada para a cultura em geral sem que, com isso, tenha seu conteúdo maculado.

${ }^{7}$ PAPA PAULO VI. Exortação apostólica Evangelii Nuntiandi sobre a evangelização no mundo contemporâneo. São Paulo: Paulinas, 1975. Doravante citado pela sigla EN.
} 
Aqui, por certo, teríamos inúmeras considerações a fazer no que diz respeito a Jesus Cristo e algumas cristologias de nosso tempo. Importa considerar que Aparecida eleva ao primeiro lugar na lista das prioridades evangelizadoras de nosso tempo a postura missionária. Não se utiliza aqui o termo no plural, quando então se deveria mencionar um dos primeiros lugares, sempre com a preocupação de não ferir suscetibilidades. Pelo contrário, é preciso insistir no fato que a consciência missionária é tão forte em Aparecida que um dos textos mais duros dentre os Documentos oficiais dos últimos tempos encontra-se exatamente em Aparecida. Trata-se do número 365, quando é solicitado ter a coragem de "abandonar as estruturas ultrapassadas que já não favoreçam a transmissão da fé". A isso, deu-se então o nome de "conversão pastoral". Esta expressão dá título ao item 7.2 do Documento e é definida no número 370, quando se diz que ela, a conversão pastoral, exige que se vá "além de uma pastoral de mera conservação para uma pastoral decididamente missionária".

Por conservação podemos entender a permanência junto às mesmas pessoas, sustentando-lhes a fé, consumindo-se no zelo por não deixar escapar os que ainda restam, com o desgaste de energias no empenho por conservar uma cristandade que já se foi. Esta é a denominada pastoral de conservação, cuja base é exatamente a cristandade, enquanto vínculo entre fé e cultura, vínculo que deixou de existir.

Nesse sentido, convém observar o que ocorreu com a expressão Missão Continental. Na fase preparatória, este termo foi utilizado como uma possível proposta de ação concreta decorrente da Conferência. Já, porém, na mesma fase preparatória, sua compreensão como evento foi questionada sob diversos aspectos. Dentre esses aspectos, emergia a dúvida a respeito da diferença entre o anúncio de Jesus Cristo e o respeito à diversidade religiosa e cultural, cada vez mais emergente. Percebia-se também o risco de se realizar práticas missionárias sob a ótica não da mudança de época, mas com os mesmos pressupostos dos períodos históricos e culturais anteriores. ${ }^{8}$ Durante o período da preparação da Conferência, havia, se assim podemos dizer, certo mal-estar evangelizador. Era sabido ser necessário um tipo de choque missionário. Alguns achavam que se deveria fazer algo ao estilo das missões populares, como uma desobriga continental para reconquistar os católicos. Já sentiam que não se tratava de uma ação pontual, com princípio e fim definidos,

\footnotetext{
${ }^{8}$ Ver, por exemplo, RELAMI. "Síntese das contribuições da Igreja no Brasil à Conferência de Aparecida", pp. 18-20. Disponível em <http://www.missiologia.org.br/wp-content/uploads/ cms_artigos_pdf_22.pdf $>$. Acesso em 9 de agosto de 2017.
} 
com cronologia e geografia delineados, mas de uma postura ou um estado permanente de missão. Com isso, a síntese das conclusões recebidas optou por não se referir a uma proposta missionária específica, deixando, ao longo do texto, o espírito missionário em estado de atenção. ${ }^{9}$

Durante a Conferência, com a clareza da decomposição da cristandade, compreendida como certo tipo de articulação entre fé e cultura, foi-se percebendo que missão não poderia se referir a uma atividade, ainda que importante, mas a uma nova postura diante da transmissão da fé, pois os caminhos até então predominantes para isso já não se mostravam tão aptos a fazê-lo. Família, escolas e outras instâncias socioculturais já não conseguiam mais apresentar Jesus Cristo e o Reino de Deus. Era preciso fazer uma passagem do implícito para o explícito. Aparecida propôs, com todo o respeito, um Jesus explícito, um processo de clara apresentação da pessoa e da mensagem de Jesus Cristo, processo talvez estranho para um mundo que navega nas águas do relativismo batizado como tolerância. Com isso, o termo missão continental permaneceu no Documento de Aparecida, já ao final, na Conclusão (DAp 551), mas como uma indicação a ser concretizada posteriormente. ${ }^{10}$ A Igreja no Brasil, apresentou um projeto evangelizador baseado no conceito de missão continental como evento, mas com abertura a um espírito missionário mais amplo. ${ }^{11}$

Interessante observar que se trata de uma compreensão que vem crescentemente marcando a reflexão magisterial da Igreja no que diz respeito aos papas do final do século XX e início do século XXI. João Paulo II já indicara essa realidade, quando cunhou, em 1983, no Haiti, o termo nova evangelização que, em Bento XVI, alguns anos depois de Aparecida, se concretizou no Ano da Fé, com a criação do respectivo Dicastério e, mais ainda, com o claríssimo diagnóstico apresentado na Porta Fidei no $2 .{ }^{12}$

Sucede não poucas vezes que os cristãos sintam maior preocupação com

\footnotetext{
${ }^{9}$ CELAM. Síntesis de los aportes recibidos para a V Conferencia General del Episcopado Latinoamericano. Bogotá: CELAM, 2007.

${ }^{10}$ Clara reflexão sobre este aspecto aparece em: QUIROGA, L. A. C. "La misión de la Iglesia en el Documento Conclusivo de Aparecida". In: CELAM (Org.). Testigos de Aparecida. Vol. II. Bogotá: CELAM, 2008, pp. 295-300.

${ }^{11}$ CONFERÊNCIA NACIONAL DOS BISPOS DO BRASIL. Projeto Nacional de Evangelização: O Brasil na Missão Continental. Documento 88. Brasília: CNBB, 2008.

${ }^{12}$ PAPA BENTO XVI. Carta apostólica sob forma de motu próprio Porta Fidei com a qual se proclama o ano da fé. São Paulo: Paulinas, 2012.
} 
as consequências sociais, culturais e políticas da fé do que com a própria fé, considerando esta como um pressuposto óbvio da sua vida diária. Ora, um tal pressuposto não só deixou de existir, mas frequentemente acaba até negado. Enquanto, no passado, era possível reconhecer um tecido cultural unitário, amplamente compartilhado no seu apelo aos conteúdos da fé e aos valores por ela inspirados, hoje parece que já não é assim em grandes setores da sociedade...

O fato é que a explicitação da pessoa e da mensagem de Jesus Cristo colocou a Igreja no chamado estado permanente de missão, o qual, antes de ser uma atividade a mais em meio às outras, todas elas de conservação, transforma em urgência a apresentação de Jesus Cristo e da comunidade dos discípulos. Dito em outras palavras, na quebra da cristandade, são recolocadas as questões sobre Jesus Cristo e a Igreja.

\section{A apresentação de Jesus Cristo}

É por causa da explicitação de Jesus Cristo, que Aparecida vai dar tanto destaque à questão do discipulado. É por isso que a segunda parte do Documento, onde se encontram, nos capítulos de 3 a 6 , as duas grandes propostas ad intra para a Igreja no Continente: a formação em estilo catecumenal numa Igreja comunidade de pequenas comunidades. Outros assuntos poderão ser encontrados nestes três capítulos, mas devemos insistir quanto ao fato de que são essas as duas grandes concretizações de Aparecida para o estado permanente de missão, num mundo para o qual a conservação não mais se aplica.

A perspectiva catecumenal está descrita no sexto capítulo, a partir do número marginal 276. Toda a formação, isto é, todo o encontro com Jesus Cristo é tratado como um processo à diferença de modelos formativos de perfil mais intelectualizante e complementar ao que a cultura cristã fornece ou deveria fornecer. $O$ fato é que, ao propor a formação do(a) cristão(ã) a partir de um processo que, iniciando-se pelos conteúdos querigmáticos, "conduza ao encontro cada vez maior com Jesus Cristo" (DAp 289), Aparecida ratifica um princípio que, lá atrás, na leitura da realidade, já se fazia presente. Se ainda estivéssemos em um tipo de cristandade, em que cultura e fé se alinham, em que o chamado catecumenato social se aplica, não haveria necessidade de questionar a fundo a maneira como estamos educando na fé e alimentando 
a experiência cristã (DAp 287) e, mais ainda, Aparecida não teria atribuído a este processo a condição de urgência (DAp 289) a ser assumida em todo o Continente (DAp 294).

Quanto à Igreja, a proposta de Aparecida encontra-se nos capítulos quinto e sexto. Tamanha é a sua importância que, neste ponto, o Documento se tornou repetitivo, ao tratar duas vezes da mesma questão. Este fato, porém, não se constitui em uma falha de revisão, mas num grito de alerta. O ponto de partida é a afirmação de que a realidade eclesial, na maioria das vezes centrada na paróquia territorial, não atinge mais um grande número de pessoas (DAp 173) nem incide sobre a sociedade e a cultura. Daí a necessidade de renovação, no rumo da configuração em uma "rede de comunidades e grupos capazes de se articular" (DAp 172). Sobre isso, haveria muito a comentar. Importa, porém, chamar a atenção para o famoso número 179 . Nele, são apresentadas as características das comunidades eclesiais de base, as CEBs. Estas, no entanto, não são características apenas das CEBs. São condições sine qua non para se viver a experiência eclesial em qualquer situação ou contexto.

\section{Aparecida não nos coloca numa guerra santa}

Quando se olha o recomeçar a partir de Jesus Cristo numa Igreja rede de comunidades, podemos ficar com a impressão de que estamos numa espécie de guerra santa light, de que estamos nos tornando intolerantes e não dialogais, de que perdemos o respeito pelos outros, de que já não somos mais uma Igreja servidora, em especial dos pobres e sofredores.

Ocorre que Aparecida não abandonou a opção preferencial pelos pobres, mas, ao contrário, alargou-a, manifestando não apenas as duas listas dos rostos sofredores (DAp 65 e 402), mas identificando o caráter inseparável de três elementos: 1) o encontro com Jesus Cristo, 2) a adesão a uma comunidade dos discípulos(as) e 3) o compromisso pela vida. Estamos, então, na terceira parte do Documento, cuja afirmação central consiste no reconhecimento de que o serviço à vida plena faz parte da missão dos(as) discípulos(as) de Jesus Cristo. Ali, à luz do Discurso Inaugural de Bento XVI, se ratifica a relação entre "a fé cristológica naquele Deus que se fez pobre por nós, para nos enriquecer com sua pobreza" (DAp 392 e DI 3) e o serviço à vida, manifestado na solidariedade às vítimas da não vida, em todas as suas formas. ${ }^{13}$

\footnotetext{
${ }^{13}$ Nesse sentido, convém avaliar bastante a concretização da solidariedade em relação aos pobres, uma vez que se tornou necessário ao Papa convocar um Dia Mundial dos Pobres, como
} 


\section{Os dez anos que se seguiram à Conferência de Aparecida}

O período de dez anos é pequeno para que se possa dizer se houve ou não efetiva captação do que aquela $\mathrm{V}$ Conferência significou. Como dito antes, Aparecida nos apresenta uma mudança diametral para a Igreja e sua ação evangelizadora. Trata-se de uma transformação que afeta compreensões milenares, pois são, a contar do período histórico de Constantino e Teodósio, aproximadamente dezessete séculos. Estamos diante de um tempo quantitativamente maior que o período em que a Igreja conviveu com o judaísmo e a etapa de contato inicial com a gentilidade. Esta transformação de $180^{\circ}$ nos diz que já não se trata de atuar somente nas consequências morais e sociais do Evangelho, pressupondo que a pessoa e mensagem Jesus Cristo sejam conhecidas e acolhidas. Não se trata de descurar das consequências existenciais do Evangelho. Trata-se de perceber a necessidade de explicitação da causa maior, o fundamento último sobre o qual se constroem as consequências. A novidade, se assim se pode dizer, está na importância de se trabalhar nos dois âmbitos, o do anúncio explícito da pessoa e da mensagem de Jesus Cristo, e nas consequências pessoais, sociais, econômicas, culturais, ecológicas, políticas etc. Infelizmente, este duplo espaço de ação nem sempre é fácil de ser concretizado.

Esta dificuldade tem, como sabemos, pelo menos duas origens. De um lado, estão os séculos de ação evangelizadora com base nas consequências. De outro, deparamo-nos com o forte dualismo antropológico que, mais ou menos com a mesma duração, acompanha a compreensão da fé, ou seja, a leitura em chave de oposição, no caso, entre o anúncio de Jesus Cristo e as consequências existenciais para quem $\mathrm{O}$ acolhe. Leituras acostumadas à cristandade, tenham estas leituras a vertente que vierem a ter, quando vivenciadas em concubinato com o dualismo, geram a incapacidade de se responder adequadamente ao momento histórico atual, que é outro de não muito tempo atrás.

interpelação à Igreja e, por seu intermédio, ao mundo diante do crescimento agudo da pobreza. PAPA FRANCISCO. "Mensagem do Santo Padre Francisco por ocasião do $1^{\circ}$ Dia Mundial dos Pobres", 13 de junho de 2017, especialmente o número 6. Disponível em < https://w2.vatican. $\mathrm{va} /$ content/francesco/pt/messages/poveri/documents/papa-francesco_20170613_messaggio-igiornatamondiale-poveri-2017.html> Acesso em 14 de junho de $201 \overline{7}$. 


\section{Aparecida na Igreja do Brasil}

A Igreja no Brasil recolheu Aparecida de diversas formas. O Documento recebeu, principalmente nos primeiros anos após sua publicação, significativa acolhida, com forte interesse por conhecer e aplicar. Em nível oficial, o Documento de Aparecida marcou gradativamente as Diretrizes para a ação evangelizadora da Igreja no Brasil, promulgadas pela Conferência Episcopal.

Desde Aparecida, já foram elaboradas três Diretrizes. As primeiras (2008-2010) manifestaram a prudência de se perceber ser necessário algum tempo a mais para que se pudesse ruminar o que Aparecida indicava. Por isso, o período foi mais breve e o gênero literário se caracterizou pelo recolher a rica experiência brasileira das Diretrizes de até então e identificar, nesta experiência, onde se encontrava Aparecida. A experiência vivida condicionava a captação de Aparecida.

As Diretrizes seguintes (2010-2015) se caracterizaram pela utilização do termo urgência em lugar de prioridade, destaque ou algum outro empregado nos planejamentos pastorais anteriores. Isso aconteceu exatamente por causa de Aparecida, porém não tanto por importação direta de um termo marcante no Documento. Ao contrário, quantitativamente, o termo urgência aparece somente três vezes ao longo de todo o texto. ${ }^{14}$ Seu uso foi motivado pela compreensão que, na época da composição daquelas Diretrizes, se fortalecia a respeito de Aparecida e do que ali era indicado. Já não se tratava de reparos pastorais, mas de efetiva transformação - daí o termo conversão pastoral! com o risco de se chegar atrasado na história. Foi por isso que estas Diretrizes, elaboradas após três anos de ruminação de Aparecida, buscaram e indicaram para a Igreja no Brasil as implicações maiores do que significa "recomeçar a partir de Jesus Cristo".

A manutenção das urgências nas atuais Diretrizes (2015-2019) e alguns processos concomitantes revelam, em primeiro lugar, que a Igreja no Brasil tem se empenhando por efetivamente assumir o caminho de Aparecida. É necessário destacar alguns documentos oficiais da Conferência Episcopal, os quais têm a dupla função de recolher as maiores preocupações e motivar que se avance na reflexão e acima de tudo nas práticas. Seria uma reflexão ainda mais longa se buscasse na vida das comunidades outros exemplos, e também

\footnotetext{
${ }^{14}$ DAp 289, 368 e 518. Interessante observar que, nos três casos, o termo urgência é aplicado à proposta central de Aparecida: iniciação cristã, conversão pastoral e grandes cidades.
} 
na produção teológica. Quanto aos documentos, devem ser destacados quatro, os quais fazem parte de um único conjunto, de uma única proposta, a qual foi dissecada em três partes para melhor ajudar a sua implementação. Citando os números pelos quais são conhecidos, o Documento 97, sobre a animação da vida e da pastoral pela Palavra de Deus, o Documento 100, a respeito das comunidades de comunidades, o Documento 105, que trata do laicato como sujeito na Igreja e na sociedade e o Documento 107, sobre a Iniciação à vida cristã. ${ }^{15}$

Como se pode ver, este é um processo ainda em curso, deixando claro que não se mudam hábitos e compreensões milenares em apenas uma década, por mais acelerados que estejam os ritmos de tempo. O importante é não parar de caminhar nem retroceder, deixando-se vencer pela saudade da cristandade.

\section{Novidades após Aparecida}

Em meio a tudo isso, estes dez anos após a Conferência de Aparecida têm sido marcados por algumas realidades que, embora presentes em 2007, explicitaram-se com maior vigor nos últimos anos e precisam ser igualmente consideradas. Destacam-se aqui apenas alguns:

10.1. Aceleração - A reconfiguração do mundo se acelerou muito nesses dez anos, gerando vazios nas mais diversas áreas da existência humana, fazendo com que todas as compreensões, leituras e captações se tornem rapidamente obsoletas. Neste processo de crise de identidades, não se pode deixar de considerar os acontecimentos que marcaram o Brasil no cenário político e econômico da última década. O detalhamento fica para uma análise de perfil mais social. Importa aqui perceber que este cenário, de alguma forma, nos atinge no estilo de evangelizar, uma vez que a evangelização não é impermeável ao que ocorre na sociedade. Uma das consequências

${ }^{15}$ CONFERÊNCIA NACIONAL DOS BISPOS DO BRASIL. Discipulos e Servidores da Palavra de Deus na Missão da Igreja. Documento 97. Brasília-DF: Edições CNBB, 2009; CONFERÊNCIA NACIONAL DOS BISPOS DO BRASIL. Comunidade de comunidades: uma nova paróquia. Documento 100. Brasília-DF: Edições CNBB, 2014; CONFERÊNCIA NACIONAL DOS BISPOS DO BRASIL. Cristãos leigos e leigas na Igreja e na Sociedade. Documento 105. Brasília-DF: Edições CNBB, 2016; CONFERÊNCIA NACIONAL DOS BISPOS DO BRASIL. Iniciação à vida cristã: itinerário para formar discípulos missionários. Documento 107. Brasília-DF: Edições CNBB, 2017. 
mais delicadas deste processo encontra-se na crise de mediações. O que, até algum tempo atrás, servia como mediação para a relação da fé com a vida, nos diversos âmbitos da vida, tem-se mostrado na última década cada vez mais frágil.

10.2. O pontificado do Papa Francisco - Em segundo lugar, encontrase o pontificado do Papa Francisco. Com dito antes, Aparecida encontra-se na base de sua proposta evangelizadora. Igreja em saída, periferias existenciais e tantas outras expressões são traduções para o cotidiano pastoral universal das indicações de Aparecida.

10.3. Consciência ecológica - Ao lado da solidariedade com as pessoas, vimos se fortalecer na consciência evangelizadora a dimensão ecológica. A Encíclica Laudato $\mathrm{Si}^{\prime 16} \mathrm{com}$ a sua perspectiva de ecologia integral, não separa as questões sociais das ecológicas. Ao contrário, integra fortemente essas duas realidades num único processo, superando as dicotomias que podem existir entre as lutas sociais e as ecológicas.

10.4. Alargamento dos púlpitos - Há dez anos atrás, Aparecida chamava a atenção para alguns novos ambientes e sua relação com a evangelização (Todo o décimo capítulo, DAp 476ss). Havermos, portanto, de considerar o quanto, nesses dez anos, cresceram, por exemplo, as redes sociais. $\mathrm{O}$ uso dos celulares como uma realidade muito além da telefonia liberou de espaço e tempo, exigindo que a ação evangelizadora não se limite a apenas esperar os fiéis chegarem no horário e no local previamente marcados. Há aqui um forte desafio no sentido de pensar o anúncio da pessoa e da mensagem de Jesus Cristo neste novo perfil de espaço e tempo.

10.5. A base testemunhal - Nesses dez anos, a plausibilidade se deslocou ainda mais das instituições para as pessoas, passou do discurso para a ação. Nosso tempo acredita mais em pessoas que comprovam o que dizem. Essa realidade traz para o primeiro lugar da ação evangelizadora hoje a questão do testemunho. Nosso tempo deparase com forte proliferação de falas, vozes, mensagens e propostas. No entanto, assim como vai atrás de falas e vozes, paradoxalmente se manifesta descrente delas. Já não quer apenas ouvir. Quer ver,

${ }^{16}$ PAPA FRANCISCO. Laudato Si'. Louvado seja sobre o cuidado da casa comum. São Paulo: Paulus/Loyola, 2015. Doravante citado pela sigla LS. 
quer comprovar. Nesse sentido, o peso do testemunho pessoal do(a) discípulo(a) missionário(a) cresce fortemente, exigindo o que Aparecida já indicava como formação permanente de cada pessoa. Não serão (apenas) pregações que convencerão, mas, acima de tudo, práticas testemunhais.

10.6. O testemunho da solidariedade - $O$ testemunho possui um rosto. Aparecida o indica através do compromisso pela vida. Como discípulos de Jesus Cristo, sentimo-nos desafiados a discernir os sinais dos tempos, à luz do Espírito Santo, para nos colocar a serviço do Reino, anunciado por Jesus, que veio para que todos tenham vida e para que a tenham em abundância (DAp 33). Por isso, o testemunho cristão, em nossos dias, não pode ser outro a não ser o compromisso com os crucificados sobre a terra e, de acordo com a crescente consciência ecológica, com a criação e sua devastação.

"Nossa fidelidade ao Evangelho exige que proclamemos a verdade sobre o ser humano e sobre a dignidade de toda pessoa humana em todos os espaços públicos e privados do mundo de hoje e a partir de todas as instâncias da vida e da missão da Igreja”. (DAp 390)

Certamente, o testemunho cristão não se resume à solidariedade. Embora mais amplo, assim como em toda a história dos discípulos missionários d'Aquele que se entregou por amor de nós até o fim (cf. Jo 13,1), também hoje esse testemunho se torne mais crucial ainda. Basta lembrar a forte presença da dimensão religiosa, aliada algumas vezes à perspectiva do mercado. Será, portanto, a solidariedade, enquanto presença gratuita junto aos pobres e sofredores, que vai permitir o diferencial em meio a outras formas de manifestar a identidade.

10.7. O testemunho da comunhão (cf. DAp cap. V) - A experiência humana de comunhão, concretizada em relações de convívio, partilha de sonhos, angústias, esperanças e sucessos (cf. DAp 156), torna-se, nos dias atuais, outra grande mediação para a compreensão do Deus que é comunhão trinitária e da solidariedade junto aos crucificados da terra (cf. DAp 163 e 
167). Por isso, é tão importante investir na experiência eclesial como comunidade de comunidades (cf. DAp 159). O Documento de Aparecida é muito claro ao se referir à reformulação das estruturas paroquiais a fim de que se possibilite a experiência de efetivo discipulado missionário (cf. DAp 172 e 365. Também o Doc. 100).

"Quanto mais a Igreja reflete, vive e comunica este dom de inaudita unidade, que encontra na comunhão trinitária sua fonte, modelo e destino, mais parece significativo e incisivo seu operar como sujeito de reconciliação e comunhão na vida de nossos povos" (DAp 524).

10.8. Quando os discursos e conceitos não satisfazem mais - Aparecida afirma o valor da piedade popular como uma das maiores riquezas de nossos povos (cf. DAp 7), lugar de autêntico encontro com Jesus Cristo (cf. DAp 258ss), com a força de penetrar delicadamente a existência de cada pessoa (cf. DAp 261). Importa que se consiga que a fé do povo amadureça e se faça mais fecunda" (cf. DAp 262). Essa importância sempre presente na vivência cristã se manifesta em nossos dias ainda maior em virtude da incapacidade dos discursos e conceitos, válidos em outros momentos históricos, responderem às questões de hoje. Nem sempre a linguagem evangelizadora é rápida o suficiente para acompanhar o fluxo acelerado de interpelações. Por isso, a piedade popular se mostra um caminho importante para ajudar na busca das respostas e, mais ainda, no solidificar das identidades. Na falha das instâncias intra-históricas para resolver os problemas do cotidiano, a piedade popular remete diretamente para Deus ou seus mediadores(as). E este tem sido um dos grandes fatores de desenvolvimento e ampliação de práticas devocionais no momento.

\section{Perspectivas ou desafios}

Ao buscar identificar as perspectivas para a apropriação e aplicação do Documento de Aparecida, devemos recordar alguns aspectos bastante desafiadores para o modo como a Igreja vai desenvolver sua ação evangelizadora. 


\subsection{O perigo do envelhecimento por decreto}

O primeiro desafio consiste em sucumbir à tendência atual de que um documento com uma ou mais décadas já esteja ultrapassado, devendo, com isso, passar para a arqueologia teológico-pastoral. A tão mencionada aceleração dos ritmos de tempo pode fazer com que, consciente ou inconscientemente, a ação evangelizadora da Igreja considere Aparecida como uma realidade ultrapassada e por isso já não desperte mais o interesse que deve continuar despertando. Nestes tempos de mudanças rápidas, de busca contínua por novidades e descrença em propostas de perfil mais estrutural, uma proposta com uma década de idade pode soar como ultrapassada. O risco aqui é grande, mesmo com a insistência do Papa Francisco em chamar a atenção para sermos uma Igreja em mudança de época. Esse desafio é grave porque esta mudança de época não passou e não sabemos se, quando nem como vai passar, pois se trata de um processo aberto. Sabemos, entretanto, que precisamos contribuir para que este processo esteja o mais próximo possível do Reino de Deus e essa é a proposta de Aparecida.

\subsection{O impasse entre o anúncio e a tolerância}

Em segundo lugar, há de se destacar o impasse entre a proposta maior de Aparecida, isto é, o recomeçar a partir de Jesus, o anunciar a pessoa e a mensagem de Jesus Cristo, por um lado, e, por outro, o reconhecimento de que vivemos não mais numa cristandade, porém num mundo crescentemente plural, em que o cristianismo é chamado a conviver com diversas outras formas de crer, inclusive de não crer. Importa recordar que o respeito ao diferente tem suas raízes no próprio cristianismo e, nesse sentido, o que hoje se tem chamado de tolerância não deixa de ter uma conotação positivamente cristã.

O desafio, porém, consiste em articular o respeito ao outro com a proposta clara e inequívoca de Aparecida. Aqui se aplica o conhecido adágio sobre a diferença entre o remédio e o veneno, que é, a dosagem. O recomeçar a partir de Jesus Cristo se torna uma urgência irrenunciável enquanto apresentação da pessoa e da mensagem, daquele que é caminho, verdade e vida (Jo 14,6). É preciso sair dos confortos pastorais e mergulhar de cabeça nessa mentalidade ou sociedade plural, porém não com uma identidade liquefeita, ainda que batizada sob o nome de tolerância ou respeito. É preciso também apresentar 
a pessoa e a mensagem de Jesus Cristo. Afinal, na Escritura também está o mandato (cf Mc 16,15). Como, pois, articular anúncio e respeito? Por outro lado, é preciso fazê-lo em perspectiva dialogal, ouvindo-se os que pensam diferentemente, reconhecendo neles(as) irmãos e irmãs e mesmo contemplando como o Espírito Santo age no meio deles(as).

\subsection{Que Jesus vamos apresentar?}

Além de refletirmos sobre o dever de apresentar Jesus, importa que também identifiquemos a que Jesus estamos nos referindo. Esta necessidade decorre da diferença entre Jesus Cristo e as cristologias ou compreensões que se tem a respeito dele. $\mathrm{O}$ acesso a Jesus é sempre mediado por um modo de O compreender, ou seja, por uma cristologia. Essas compreensões de Jesus Cristo de algum modo sempre estiveram presentes na vida da Igreja, sendo, por assim dizer, a mãe dos embates e das heresias. Pode-se discutir sobre o que for. No final, porém, o que se terá será sempre uma compreensão a respeito de Jesus Cristo.

Atualmente, dentre outras formas de sistematizar essas compreensões e utilizando as categorias de Aparecida, vemos um forte embate entre o Jesus do discipulado e o Jesus da prosperidade. O Jesus da prosperidade é aquele Jesus que, excessivamente imanentizado, existe e é apresentado para solucionar angústias. É o Jesus (quase que) exclusivamente para a solução de problemas. O importante, nesse tipo de compreensão de Jesus, acaba não sendo o próprio Jesus, mas o que Ele é capaz de fornecer. Quando não fornece, a responsabilidade é colocada nas costas do(a) já sofrido(a) suplicante, sendo este pensamento gerador de ateísmos e outras crises existenciais. Nesse sentido, existe no Documento de Aparecida uma pérola cristológica, a saber, o número 131.

O chamado que Jesus, o Mestre, faz, implica numa grande novidade. Na antiguidade, os mestres convidavam seus discípulos a se vincular com algo transcendente e os mestres da Lei propunham a adesão à Lei de Moisés. Jesus convida a nos encontrar com Ele e a que nos vinculemos estreitamente a Ele porque é a fonte da vida (cf. Jo 15,1-5) e só Ele tem palavra de vida eterna (cf. Jo 6,68). Na convivência cotidiana com Jesus e na confrontação com os seguidores de outros mestres, os discípulos logo descobrem duas coisas originais no relacionamento com Jesus. Por um lado, não foram eles 
que escolheram seu mestre foi Cristo quem os escolheu. E por outro lado, eles não foram convocados para algo (purificar-se, aprender a Lei...), mas para Alguém, escolhidos para se vincular intimamente a sua pessoa (cf. Mc 1,$17 ; 2,14)$. Jesus os escolheu para "que estivessem com Ele e para enviá-los a pregar" (Mc 3,14), para que o seguissem com a finalidade de "ser d'Ele" e fazer parte "dos seus" e participar de sua missão. O discípulo experimenta que a vinculação íntima com Jesus no grupo dos seus é participação da Vida saída das entranhas do Pai, é se formar para assumir seu estilo de vida e suas motivações (cf. Lc 6,40b), viver seu destino e assumir sua missão de fazer novas todas as coisas.

\subsection{O rosto da Igreja}

Assim como devemos nos perguntar a respeito de que Jesus estamos falando, devemos igualmente nos indagar a que Igreja estamos nos referindo. Dito de modo mais simples, qual o modelo, rosto ou perfil de Igreja que nossas ações evangelizadoras estão transmitindo. Não se pode negar que não temos nem podemos ter um único rosto de Igreja. ${ }^{17}$ Já as primeiras comunidades manifestavam essa diversidade. Os textos neotestamentários e os subsequentes mostram a preocupação em manter o essencial e respeitar a pluralidade. Essa preocupação diz respeito a se manter a identidade da Igreja, enquanto comunhão dos diversos.

Em nossos dias, assim como percebemos um embate entre compreensões a respeito de Jesus Cristo, também podemos perceber um embate a respeito das compreensões sobre o jeito de ser Igreja. Por um lado, temos a proposta de Aparecida já presente em Santo Domingo (SD 58ss) de uma Igreja comunidade de comunidades. ${ }^{18}$ De outro, deparamo-nos com formas contemporâneas de prestação de serviços. Por certo, nossas dores muitas vezes só encontram acolhida no campo religioso, na relação com Deus. Há, porém, de se manifestar forte receio de que a apresentação da fé predominantemente como solução para os problemas seja o perfil de igreja que está emergindo aqui e acolá.

Ao Jesus Cristo da prosperidade corresponde um jeito de ser Igreja que, trabalhando com a plataforma da piedade popular, acaba por, algumas

\footnotetext{
${ }^{17}$ Cf. MIRANDA, M. F. Igreja e sociedade. São Paulo: Paulinas, 2009, p. 144.

${ }^{18}$ A expressão comunidade de comunidades aparece quatro vezes no Documento de Aparecida: 99e, 170, 179 e 309. A força, entretanto, de sua presença é considerável.
} 
vezes, ingressar no borbulhante mercado religioso de nossos dias. Por certo, não se trata aqui de negar o valor da piedade popular. Seria irresponsabilidade cristã fazê-lo. Seria negar o Documento de Aparecida (DAp 258ss). A questão aqui nem é a piedade popular, cujo valor é grande, principalmente como expressão da fé nas épocas históricas de crise dos discursos e conceitos. Tudo vai depender de como essa piedade se articula com Jesus Cristo e com a Igreja.

\subsection{O compromisso pela vida}

As compreensões de Jesus Cristo e da Igreja se definem um pouco mais quando, na linha do que Aparecida indicou, se vive o compromisso pela vida. O lema da Conferência indicava, em sua última parte, a expressão "para que nele (Jesus Cristo), os povos tenham vida". Ao longo de todo o Documento, percebemos forte preocupação com os sofrimentos das pessoas e dos povos latino-americanos e caribenhos. Por duas vezes, como referido anteriormente, são apresentadas listas de pobres e sofredores. ${ }^{19}$ Estas listas, já presentes em Puebla (PB 31ss), não são exaustivas, mas, ao contrário, apenas exemplificam um processo que desafia o mundo todo e, mais ainda, quem segue o Cristo e o Cristo Crucificado, loucura e escândalo (cf. 1 Cor 1,18). Aparecida segue a linha de Mt 25,34ss, no sentido de que os cristãos sempre viram, em cada sofredor, o Senhor Crucificado. Nesses dez anos, fomos brindados pela Encíclica Laudato Si', a qual, além de trazer para o núcleo das prioridades evangelizadoras a questão ecológica, não coloca em chave de oposição o social e o ecológico, mas, ao contrário - e aqui está uma de suas grandes riquezas! - compreende essas duas realidades como ligadas diretamente:

“...hoje, não podemos deixar de reconhecer que uma verdadeira abordagem ecológica sempre se torna uma abordagem social, que deve integrar a justiça nos debates sobre o meio ambiente, para ouvir tanto o clamor da terra como o clamor dos pobres" (LS 49).

"Estas situações provocam os gemidos da irmã terra, que se unem aos gemidos dos abandonados do mundo, com um lamento que reclama de nós outro rumo" (LS 53).

${ }^{19}$ DAp 65 e 402 . Acrescentando-se aqui as reflexões dos números 257, 407-430. 
Importa, consequentemente, estar atento para o modo como se vai lidar com o desafio da crescente desvalorização da vida diante do desafio de repensar e organizar o mundo. Não há dúvida de que é preciso contribuir para um novo rosto de sociedade, de cultura, de justiça, de democracia e assim por diante. Não podemos, é certo, achar que vamos inventar a roda, mas devemos reconhecer que Aparecida nos alerta para o fato de que, também no nível da relação com o mundo, somos desafiados a não nos omitirmos, retornando para dentro do casco, à semelhança de uma assustada tartaruga. Onde a vida estiver ameaçada, aí devem estar os discípulos missionários de Jesus Cristo.

\section{Conclusão: manter firmemente o rumo}

Enfim, a questão central de Aparecida é a de que estamos experimentando uma mudança diametral no modo de compreender a ação evangelizadora, a ponto de, internamente, modelar as comunidades e, externamente, incidir na sociedade e na cultura (cf.0 DAp 371). E isso não é tão simples de realizar. Não se pode negar que, nesta última década, surgiu uma espécie de fadiga e desânimo em relação a projetos de longo prazo. Os altos índices de violência, a frustração diante de um Brasil e de um mundo que experimentam inúmeras turbulências e o crescimento de uma religiosidade de mercado podem levar à inconsciente descrença no caminho de Aparecida. Entretanto, a angústia diante da aceleração das sequelas não nos pode mudar a meta. Ela, ao contrário, solicita a aceleração de alguns passos.

\section{Referências bibliográficas}

BENI DOS SANTOS, B. "A identidade da Igreja latino-americana de Medellín a Santo Domingo". Revista de Cultura Teológica 2 (1993), pp. 7-17.

CELAM. Documento de Aparecida. Texto conclusivo da V Conferência Geral do Episcopado Latino Americano e do Caribe. Brasília-DF/Rio de Janeiro: Edições CNBB/Paulus/Paulinas, 2007.

CELAM. Síntesis de los aportes recibos para la V Conferencia General del Episcopado Latinoamericano. Bogotá: CELAM, 2007.

CONFERÊNCIA NACIONAL DOS BISPOS DO BRASIL. Discípulos $e$ Servidores da Palavra de Deus na Missão da Igreja. Documento 97. BrasíliaDF: Edições CNBB, 2009. 
CONFERÊNCIA NACIONAL DOS BISPOS DO BRASIL. Comunidade de comunidades: uma nova paróquia. Documento 100. Brasília-DF: Edições CNBB, 2014.

CONFERÊNCIA NACIONAL DOS BISPOS DO BRASIL. Cristãos leigos e leigas na Igreja e na Sociedade. Documento 105. Brasília-DF: Edições CNBB, 2016.

CONFERÊNCIA NACIONAL DOS BISPOS DO BRASIL. Iniciação à vida cristã : itinerário para formar discípulos missionários. Documento 107. Brasília-DF: Edições CNBB, 2017.

CONFERÊNCIA NACIONAL DOS BISPOS DO BRASIL. Projeto Nacional de Evangelização: O Brasil na Missão Continental. Documento 88. Brasília: CNBB, 2008.

MIRANDA, M. F. Igreja e Sociedade. São Paulo: Paulinas, 2009.

QUIROGA, L.A.C. "La misión de la Iglesia en el Documento Conclusivo de Aparecida". In: CELAM (Org.). Testigos de Aparecida. Vol. II. Bogotá: CELAM, 2008, pp. 295-300.

PAPA BENTO XVI. Carta apostólica sob forma de motu próprio Porta Fidei com a qual se proclama o ano da fé. São Paulo: Paulinas, 2012.

PAPA FRANCISCO. Evangelli Gaudium. A alegria do Evangelho sobre o anúncio do Evangelho no mundo atual. São Paulo: Paulus/Loyola, 2013.

PAPA FRANCISCO. Laudato Si'. Louvado seja sobre o cuidado da casa comum. São Paulo: Paulus/Loyola, 2015.

PAPA FRANCISCO. "Mensagem do Santo Padre Francisco por ocasião do $1^{\circ}$ Dia Mundial dos Pobres”, 13 de junho de 2017, especialmente o número 6. Disponível em < https://w2.vatican.va/content/francesco/pt/messages/poveri/ documents/papa-francesco_20170613_messaggio-i-giornatamondialepoveri-2017.html> Acesso em 14 de junho de 2017.

PAPA PAULO VI. Exortação apostólica Evangelii Nuntiandi sobre a evangelização no mundo contemporâneo. São Paulo: Paulinas, 1975.

RELAMI. "Síntese das contribuições da Igreja no Brasil à Conferência de Aparecida", pp. 18-20. Disponível em <http://www.missiologia.org.br/wpcontent/uploads/cms_artigos_pdf_22.pdf $>$. Acesso em 9 de agosto de 2017.

STANOVINIC, A. "El método ver-juzgar-agir en Aparecida". In: 
CELAM (Org.). Testigos de Aparecida. Vol. II. Bogotá: CELAM, 2008, pp. 103-135.

\author{
D. Joel Portella Amado \\ Doutor em Teologia Sistemático Pastoral \\ pela Pontifícia Universidade Católica do Rio de Janeiro \\ Professor na Pontifícia Universidade Católica do Rio de Janeiro \\ Rio de Janeiro / RJ - Brasil \\ E-mail: joelamado@puc-rio.br
}

Recebido em: $12 / 12 / 16$

Aprovado em: 27/12/16 